\title{
Analyses of yield related agronomic traits of Malaysian rice varieties
}

\author{
Nur Aini Mohd Kasima, Chui-Yao Teh ${ }^{b}$, Parameswari Namasivayam ${ }^{a}$, Nur Fatihah Mohd. Yusoffa, Chai- \\ Ling $\mathrm{Ho}^{\mathrm{a}^{*}}$ \\ ${ }^{a}$ Department of Cell and Molecular Biology, Faculty of Biotechnology and Biomolecular Sciences, Universiti Putra Malaysia, 43400 UPM \\ Serdang, Selangor, Malaysia \\ ${ }^{b}$ School of Biological Sciences, Faculty of Science and Technology, Quest International University Perak, 30250 Ipoh, Perak, Malaysia
}

Received 17th April 2020 / Accepted 27th June 2020

\begin{abstract}
Analyses of morphological and agronomic traits not only provide important information in the selection of rice varieties for breeding, these data are also important in deciding plant materials for molecular characterization and analysis of phenotypic traits of interest. The aim of the present study was to collect, analyze and compare the agro-morphological data of 6 upland rice and 17 lowland rice varieties (Oryza sativa L.) from the Malaysian rice germplasms grown under the same greenhouse condition. The common factors that contributed to yield per plant in both upland and lowland rice varieties are plant height and percentage of filled grains. Panicle length was positively correlated to grain yield in upland rice varieties while many other agronomic traits could affect the yield per plant in lowland rice varieties such as total number of tillers, total number of panicles per plant, flag leaf width and days-to-flowering. The upland rice varieties have a slightly higher average total grain number per panicle in compensation of a low number of panicles. The compensation in total grain numbers per panicle was not sufficiently significant to affect the total yield per plant most probably due to a low total number of grains per plant. Despite a high 100-grain weight in general, some of these upland rice varieties have more than $50 \%$ percentage of unfilled grains. Data on these rice germplasms may offer information on a valuable gene pool which can be utilized in different varietal improvement/development program in future.
\end{abstract}

Keywords: lowland, Malaysian rice varieties, reproductive traits, upland, vegetative traits, yield

\section{INTRODUCTION}

Rice germplasms serve as the genetic resources for rice breeding programs because they provide the alleles for important traits necessary for improving and developing new breeds of rice varieties. These data are also important in deciding plant materials for molecular characterization and analysis of phenotypic traits of interest. The International Rice Genebank at the International Rice Research Institute (IRRI) has a collection of more than 130,000 accessions of cultivated and wild rice species. More than 90\% of the International Rice Genebank accessions have been scored for 44 morphological and agronomic traits (www.irri.org/international-ricegenebank).

For Malaysian rice germplasms that are not among the International Rice Genebank accessions, limited data are available except for those that are planted commercially by farmers. The lack of official documentation and publication on their morphological and agronomic rice traits especially those related to upland rice varieties hampers the sharing of these data among researchers on rice germplasms.

*Author for correspondence: Chai-Ling Ho, Department of Cell and Molecular Biology, Faculty of Biotechnology and Biomolecular Sciences, Universiti Putra Malaysia, 43400 UPM Serdang, Selangor, Malaysia.

Email-clho@upm.edu.my 
Despite the ability of upland rice varieties to withstand drought and ability to grow in rainfed environment, meagre attempts have been made for the improvement of these rice genotypes. Since the morphological and agronomic traits of most of the upland rice varieties are not well characterized and documented, collection and evaluation of the agronomical traits of these untapped germplasms are necessary. Systematic characterization of these germplasms enables identification of donors with appropriate attributes. The availability of these data not only important for local communities, they may also serve as important references for rice researchers from other countries to improve and develop new breeds of rice varieties. For example, Mahsuri (also known as Ponni in certain parts of India) which was developed and released by Malaysia in 1965 has become a popular rice variety to the Indian farmers, and widely used for rice breeding (Guvvala et al., 2013).

Many publications reported the agromorphological traits of rice germplasms from different countries (Pachauri et al., 2017; Narenoot et al., 2017; Efendi et al., 2015; Parikh et al., 2012; Sohrabi et al., 2012; Nascimento et al., 2011; Dong et al., 2010; Fukuoka et al., 2006; Zeng et al., 2003; Patra and Dhua 2003; Li et al., 2000). Many of these morphological and agronomic traits are dependent on changes in environmental factors hence data collected by individual groups or institutions on some of these rice varieties under different planting conditions may not be suitable for accurate comparison. The aim of the present study was to collect, analyze and compare the morphological and agronomic traits of 6 upland and 17 lowland rice varieties (Oryza sativa L.) from the Malaysian rice germplasms grown under the same greenhouse condition. The association amongst yield related traits may help to determine the usefulness of the germplasms for breeding and enables the selection of the most effective breeding strategies.

\section{MATERIALS AND METHOD}

\section{Plant materials}

Rice seeds of 23 Malaysian rice varieties were obtained from the Rice Genebank, Malaysian
Agricultural Research and Development Institute (MARDI) (Kepala Batas, Penang, Malaysia) (Table S1). The upland rice varieties in this study (except for Kuku Balam) which are commonly cultivated at Tuaran District (Sabah, Malaysia) were obtained from a local rice seed supplier (Kebun Bahagia Bersama, Sungai Buloh, Selangor, Malaysia). The lowland rice varieties in this study are from the indica subpopulation except of Mahsuri which is a derivative of indica/japonica (http://www.fao.org/3/y4751 e0b.htm). The genetic background of the upland rice varieties is unknown except for Kuku Balam which is from the indica subpopulation while Taragang and Tomou are most probably from the tropical japonica subpopulation (Teh et al., 2019).

\section{Rice planting}

Rice planting was conducted in a greenhouse with transparent roof and wire mesh fencing located at Ladang 2 (300'33.6"N 101²4'20.1"E), Universiti Putra Malaysia (UPM) from February until July 2018. The average natural light intensity in the greenhouse was around $1,100 \mu \mathrm{mol} / \mathrm{m}^{2} / \mathrm{s}$. Two independent experiments were set up using randomised complete block design (RCBD) with five replications for lowland and upland rice, respectively. Seeds of each variety were treated with $20-40 \%$ (v/v) of Clorox ${ }^{\circledR}-B l e a c h$ for $30 \mathrm{~min}$ and placed on moist filter paper for germination. The seedlings were transplanted at 14-day post germination, with one seedling per pail. The planting of lowland rice varieties was conducted in pails filled with $15 \mathrm{~kg}$ of paddy soil obtained from a rice growing area Sabak Bernam District (Selangor, Malaysia) each. For the planting of upland varieties, the pails were perforated at the bottom to drain excess water and filled with $15 \mathrm{~kg}$ of well-pulverised soil. The management practices including watering, weeding and spraying were performed according to Nwilene et al. (2008) and Oikeh et al. (2008) while fertilizer was applied according to the guidelines of the Department of Agriculture, Malaysia (Berahim et al., 2014).

\section{Data collection}

Data on 14 quantitative agronomic and morphological traits were recorded for all rice varieties at each replication based on a standard evaluation system (SES) introduced by IRRI. The parameters recorded included plant height, days- 
to-flowering, flag leaf length, flag leaf width, total number of tillers per plant, total number of panicle per plant, panicle length, total number of grains per panicle, total number of filled spikelet, total number of unfilled spikelet, one hundred grain weight (100-GW), grain width, grain length, and yield per plant (Table S2).

\section{Statistical data analysis}

Statistical analysis was conducted with SPSS statistical package version 22. Differences among rice varieties were analysed using analysis of variance (ANOVA). Significant differences among mean values (at $\mathrm{p}<0.05)$ were estimated using Duncan's new multiple range test. Pearson's correlation test was conducted to examine the correlations between traits of lowland and upland rice varieties, respectively. The correlation coefficient ( $r$ ) was considered significant at $\mathrm{p}<0.05$, and highly significant at $\mathrm{p}<0.01$. Traits with $r \geq 0.5$ and $r \leq-0.5$ were considered to have strong positive and negative correlations, respectively; while traits with $0.3<\mathrm{r}<0.5$ or -0.5 $<\mathrm{r}<-0.3$ were considered to have moderate correlations; and traits with $-0.3<\mathrm{r}<0$ were considered to have weak correlations.

\section{RESULTS AND DISCUSSION}

\section{Vegetative traits of lowland rice varieties}

The plant height of 17 lowland rice varieties ranged from 95-160 $\mathrm{cm}$ (Figure 1a). The two tallest rice varieties were Mahsuri $(160.60 \pm 1.34$ $\mathrm{cm})$ and Bahagia $(130.80 \pm 6.02 \mathrm{~cm})$ while the shortest rice variety was MR263 $(95.00 \pm 2.00 \mathrm{~cm})$. A few rice varieties i.e. Mahsuri, MR219, MR220CL2, MR263, MR269, MR284 and SIRAJ MARDI, were found to be taller than that reported by the Department of Agriculture, Malaysia (http://pvpbkkt.doa.gov.my/) and MARDI (Zainuddin et al., 2012). Plant height in rice is related to the elongation of internodes (Zhang et al., 2017). Since reduction in plant height may improve the resistance of rice plants to lodging and the associated reduction yield losses, shorter rice varieties may of preference. Since the illumination in the open field condition was not measured in this study, we have no information whether the illumination in the greenhouse was lesser than that in the open field, causing the plants thrived for more illumination by growing taller.

The days-to-flowering marked the time taken for a rice plant to reach reproductive phase. Figure $1 \mathrm{~b}$ shows the length of vegetative phase of lowland rice varieties which ranged from 104-151 days-to-flowering. The rice varieties that showed earlier flowering (104-108 days) were MR219, MR220-CL2, MR263, MR284 and Ria while the rice varieties that flowered late (149-151 days) included Mahsuri and Sekembang. In this study, the flowering time of Mahsuri and MARDI SIRAJ was later than that recorded by MARDI (i.e. 10 days later for Mahsuri; and 8-10 days later for MARDI SIRAJ) while Ria was found to flower earlier i.e. about 20 days earlier compared to the data provided by MARDI. Most of the modern rice varieties released by MARDI have a shorter duration of vegetative stage. Early flowering varieties were preferred by local rice farmers because rice varieties with a shorter rice life cycle enables the farmers to plant at least two cycles per year to increase their incomes per annum.

Two flag leaf features: leaf length and width were measured in this study. The flag leaf length of the lowland rice varieties ranged from 31-43 $\mathrm{cm}$, with the shortest in Seberang and the longest in Ria and Sekembang (Figure 1c). The flag leaf width of lowland rice varieties ranged from 1.46$2.10 \mathrm{~cm}$, which was the narrowest in Sekembang and the widest in Bahagia and Seberang (Figure 1d). The number of tillers of lowland rice varieties ranged from 13-26 (Figure 1e). The rice varieties with the least number of tillers were MR284, MR263 and MR220-CL2 while the rice varieties with the highest number of tillers were Murni and Jaya. Although the number of culms per square meter and grain yields per panicle contribute to the yield per plant (Jennings et al., 1989), a moderate number of vigorous early tillers are advantageous to produce a maximum yield (Counce et al., 1996). 
a

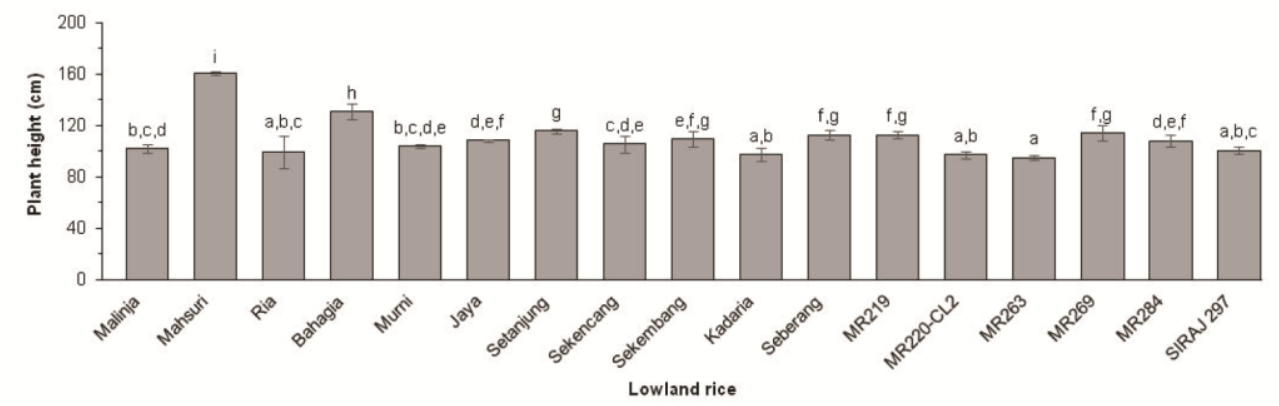

b



C

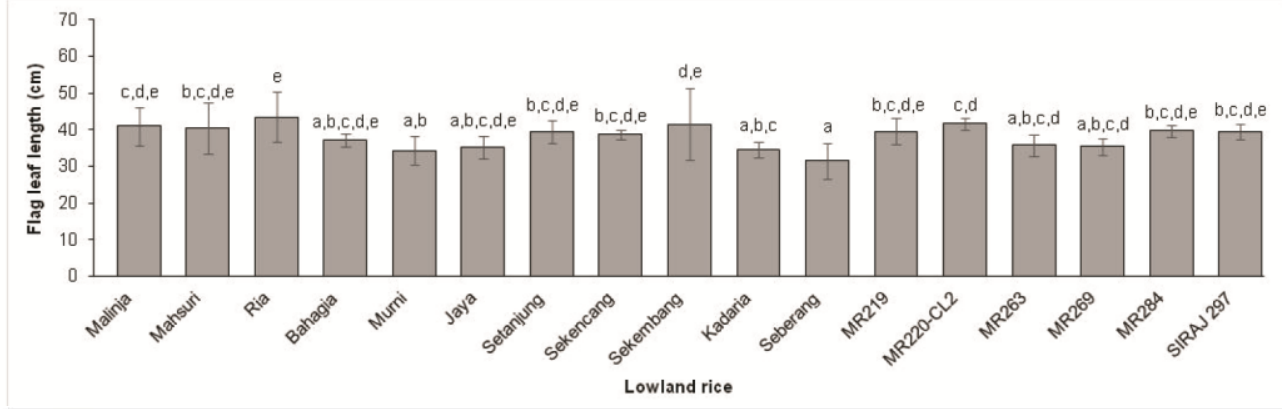

d

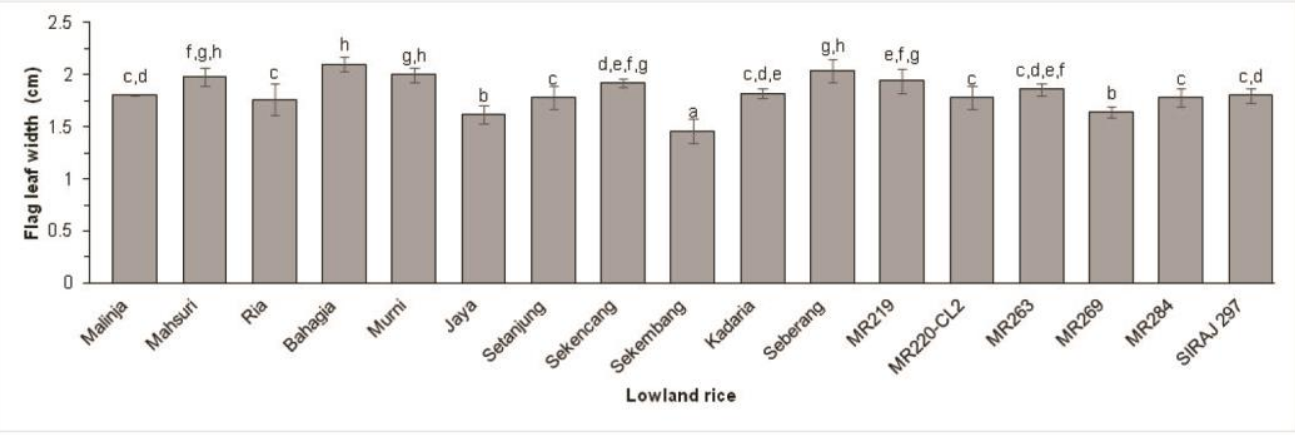

e

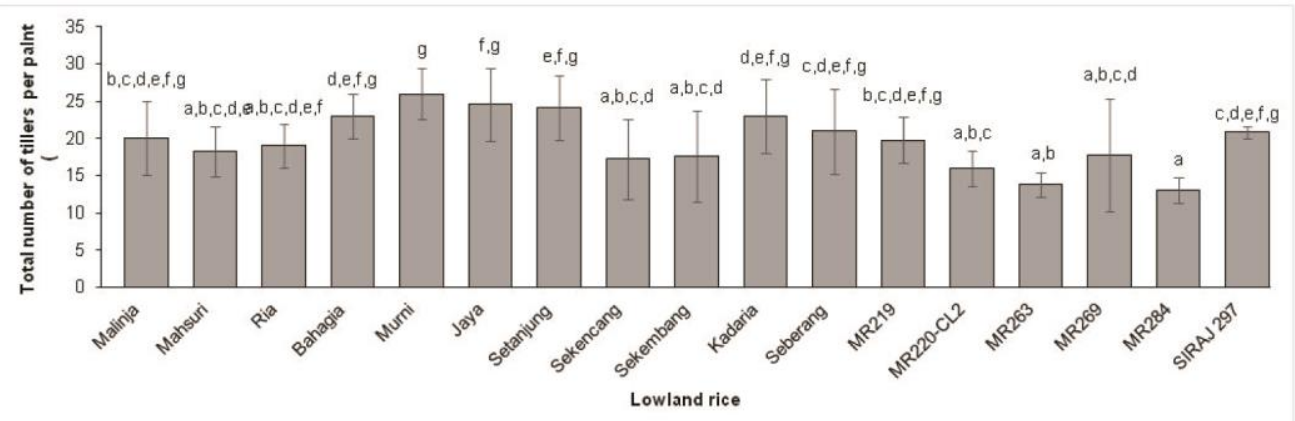

Figure 1. Comparison of vegetative traits from 17 lowland rice varieties. a, Plant height; b, Days to flowering; c, Flag leaf length; d, Flag leaf width; e, Total number of tiller per plant. Statistically significant difference between the means $(p<0.05)$ is indicated by different letters. 


\section{Yield traits of lowland rice varieties}

The number of panicles of these lowland rice varieties ranged from 12-24 (Figure 2a). The differences between the number of tillers and the number of panicles were 1-2 hence almost all tillers were productive and bear panicles. The panicle length (Table S3) of lowland rice varieties ranged from $21.98-27.08 \mathrm{~cm}$, with the shortest panicle length in Seberang and the longest in Bahagia. Malinja, MR219, MR220-CL2 and MR263 have a panicle length above the mean panicle length $(24.20 \pm 1.30 \mathrm{~cm})$. The panicle length of these rice varieties is within the range reported by MARDI (Table S1). The panicle length of Malinja $(26 \mathrm{~cm})$, MR219 $(23-26 \mathrm{~cm})$, MR220-CL2 $(23 \mathrm{~cm})$ and MR263 $(23-26 \mathrm{~cm})$ reported by MARDI was indicated in the parentheses after each rice variety.

The total number of rice grains per plant ranged from 128-305. Among the rice varieties, Mahsuri and Bahagia have the highest number of rice grains per plant $(305.40 \pm 40.72$ and $223.80 \pm 26.06$, respectively) while Murni has the least number of rice grains (128.00 1 15.73) (Figure $2 \mathrm{~b})$. The percentage of filled grains in rice varieties ranged from $23-77 \%$, with the lowest percentage in Jaya $(23.05 \pm 15.54 \%)$ and the highest percentage in Mahsuri (77.29 $\pm 4.29 \%$ ). Mahsuri which has the highest total number of rice grains (305.40 \pm 40.72 ) also has the highest percentage of filled grains $(77.29 \pm 4.29 \%)$. Bahagia which has the second highest number of total rice grains (223.80 \pm 26.06 ) has only 37\% filled grains (Figure 2c).

The 100-GW of these rice varieties ranged from $1.40-2.56 \mathrm{~g}$, with the lowest for Mahsuri $(1.40 \pm 0.07 \mathrm{~g})$ and Kadaria $(1.56 \pm 0.09 \mathrm{~g})$ while the highest for Ria $(2.52 \pm 0.04 \mathrm{~g})$ and Malinja $(2.36 \pm 0.15 \mathrm{~g})$ (Figure $2 \mathrm{~d})$. The rice varieties planted in this study achieved $80 \%-93 \%$ of the 100-GW documented by MARDI, except for Bahagia and MR284 that have less than $80 \%$ of the 100-GW documented (http://pvpbkkt.doa. gov.my/; Zainuddin et al., 2012). The grain width ranged from $0.21-0.27 \mathrm{~cm}$, with the lowest width in Kadaria and the highest width in Ria, Bahagia and Setanjung. The grain length ranged from 0.71 $\mathrm{cm}$ in Mahsuri to $0.97 \mathrm{~cm}$ in SIRAJ297 (Figure 2f). Mahsuri which is a hybrid between japonica and indica has the shortest grains and an average grain width (Figure $2 \mathrm{~g}$ ). The grain length and grain width recorded for MR219, MR220-CL2, MR263 and MR269 in this study were within the range documented by MARDI (Zainuddin et al., 2012; http://www. mada.gov.my/?page_id=13017). Nevertheless, MR284 was found to have a longer grain length and shorter grain width than those documented by MARDI. The yield per plant ranged from 16-57 $\mathrm{g}$ per plant. MR284 $(16.76 \pm 4.72 \mathrm{~g})$ has the lowest yield while Mahsuri $(56.81 \pm 17.13 \mathrm{~g})$ has the highest yield (Figure 2e). Bahagia (52.14 $\pm 7.96 \mathrm{~g}$ ) ranked the second in yield after Mahsuri. MR219 (one of the favourite rice varieties of Malaysian farmers) achieved $45.99 \pm 11.19 \mathrm{~g}$ per plant in yield.

\section{Factors affecting yield of lowland rice varieties}

Table 1 shows the Pearson correlation coefficients among of the agronomical traits of lowland rice varieties being analyzed in this study. The plant height was negatively correlated to 100 GW ( $\mathrm{r}=-0.443 ; \mathrm{p} \leq 0.01)$. However, plant height was found to be positively correlated to yield per plant $(\mathrm{r}=-0.441 ; \mathrm{p} \leq 0.01)$; possibly by having a higher number of grains per panicle, percentage of filled grains, wider flag leaves and prolonged vegetative phase whereby the plants can accumulate more photosynthates for grain filling. Grain yield was also shown to have significant positive association with days-to-flowering and panicle length in rice by other study (Asante et al., 2019).

The length of flag leaves was found to be positively correlated to panicle length and total number of grains per panicle since rice varieties with longer panicle also tend to have a higher number of grains per panicle (Table 1). With a greater number of grains per panicle, a higher grain yield can be achieved. Leaf attributes such as leaf area which depends on leaf length and width were also found to be correlated with the number of grains per panicle and grains weight per panicle by Efendi et al. (2015). 
a

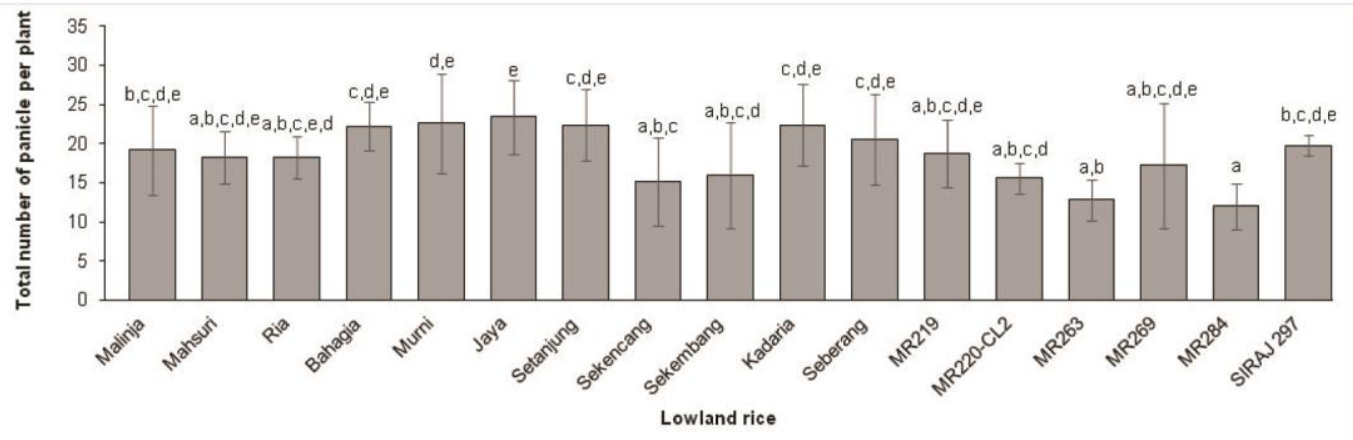

b

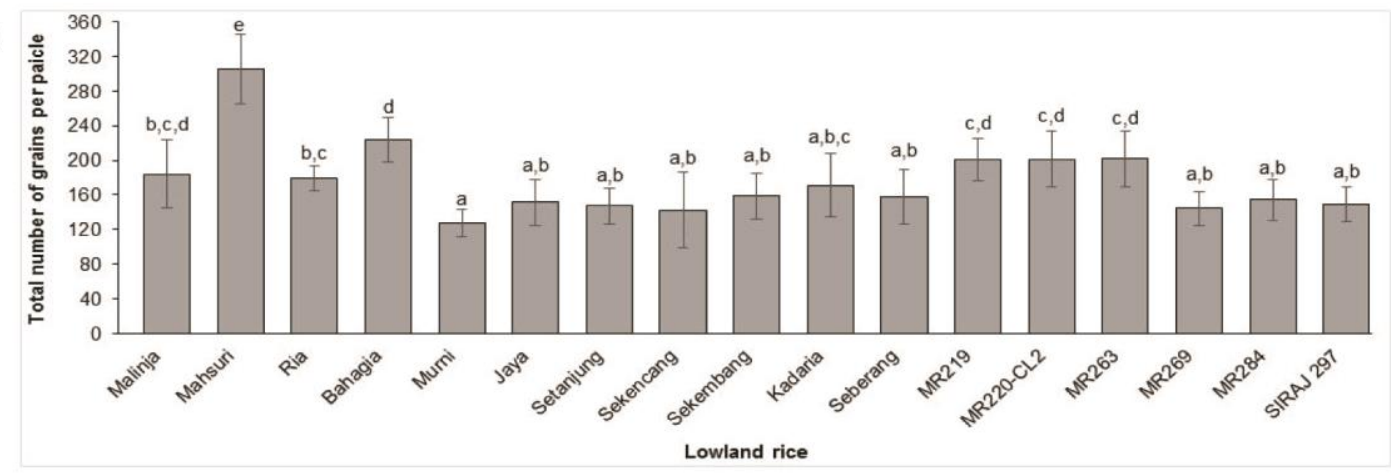

C

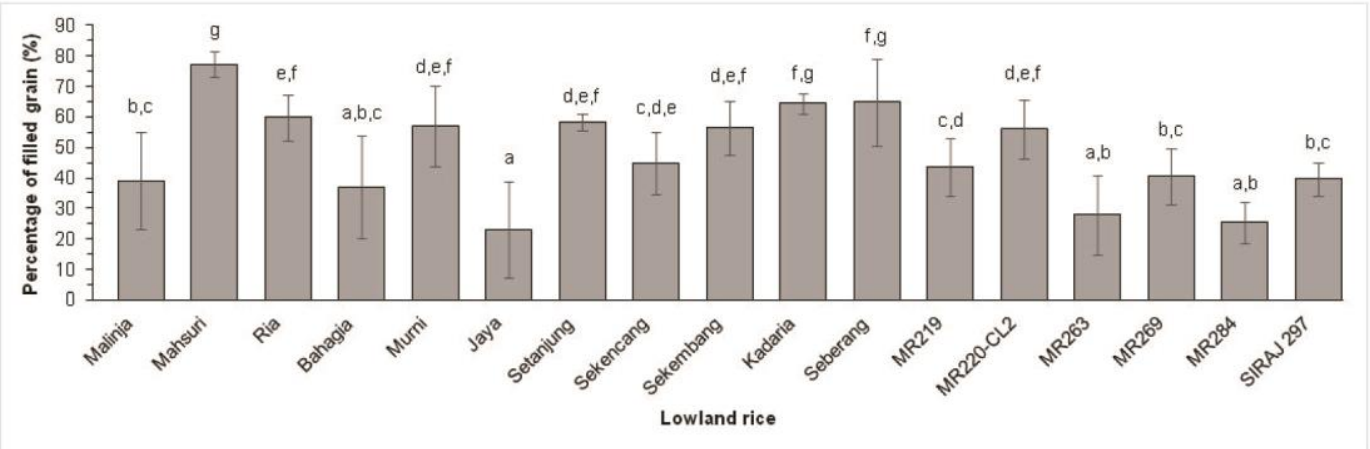

d

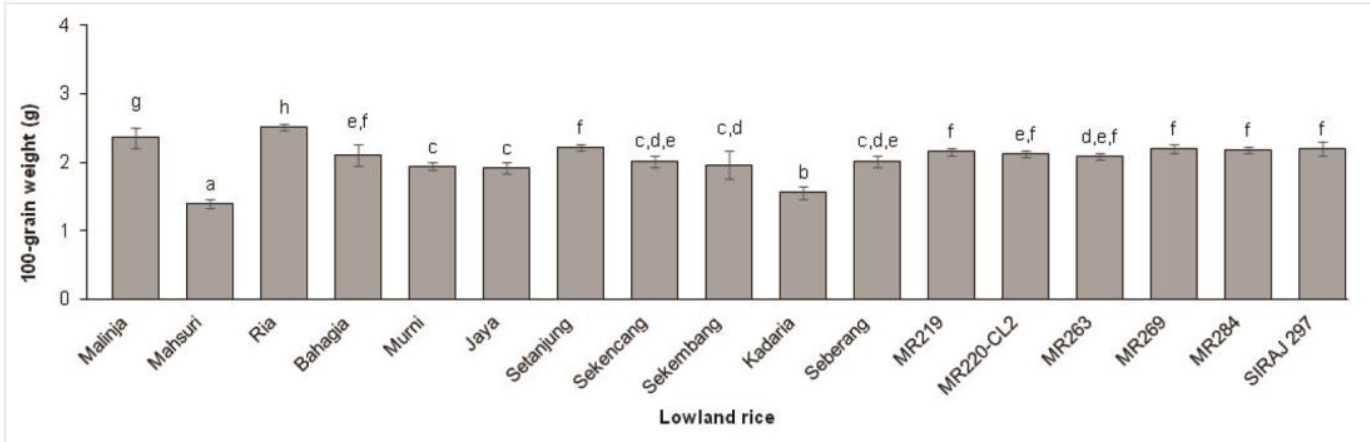

e




f
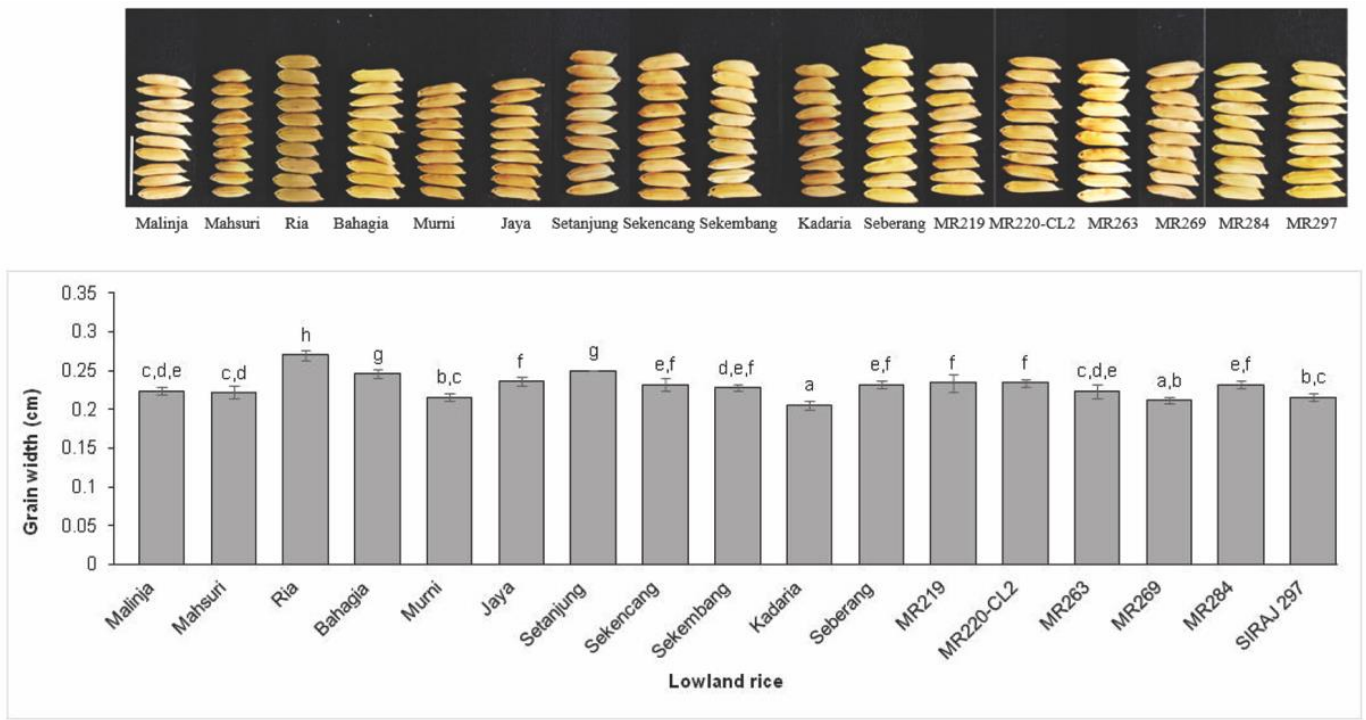

g


Figure 2. Comparison of yield traits from 17 lowland rice varieties. a, Total number of panicle; b, Total number of grains; c, Percentage of filled grains; d, 100-grain weight; e, Yield per plant; f, Grain width; g, Grain length. Scale bar $=1 \mathrm{~cm}$. Statistically significant difference between the means $(p<0.05)$ is indicated by different letters. 
Table 1. Pearson's correlation coefficient among agronomical traits of lowland (lower left triangle) and upland (upper right triangle) rice varieties.

\begin{tabular}{|c|c|c|c|c|c|c|c|c|c|c|c|c|c|}
\hline & $\begin{array}{l}\text { 흠 } \\
\frac{.0}{\Phi} \\
\frac{5}{5} \\
\frac{\pi}{0}\end{array}$ & 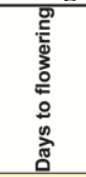 & 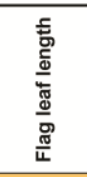 & $\begin{array}{l}\frac{5}{5} \\
\frac{0}{3} \\
\frac{\pi}{\pi} \\
\frac{\pi}{0} \\
\frac{\pi}{4}\end{array}$ &  & 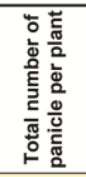 & 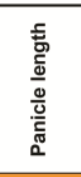 & 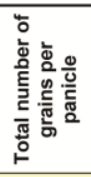 & 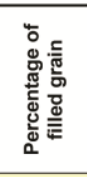 & 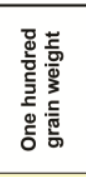 &  & 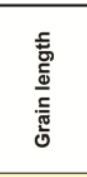 & 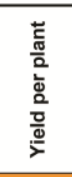 \\
\hline Plant height & & 0.013 & 0.341 & 0.221 & 0.265 & 0.185 & $0.670^{\star *}$ & 0.268 & 0.090 & 0.153 & 0.338 & -0.218 & $0.622^{\text {** }}$ \\
\hline Days to flowering & $0.507^{\star \star}$ & & $0.548^{\star \star}$ & $-0.444^{*}$ & 0.171 & 0.314 & 0.021 & 0.043 & $-0.533^{\star \star *}$ & $-0.384^{\star}$ & -0.354 & $0.399^{\star}$ & -0.070 \\
\hline Flag leaf length & 0.038 & -0.119 & & -0.122 & $0.468^{* *}$ & $0.384^{*}$ & $0.465^{\star *}$ & 0.352 & $-0.671^{\star \star}$ & -0.332 & -0.221 & $0.406^{\star}$ & 0.071 \\
\hline Flag leaf width & $0.335^{\star \star}$ & 0.107 & -0.152 & & -0.154 & -0.140 & 0.225 & 0.033 & $0.563^{\star \star \star}$ & 0.356 & $0.494^{* *}$ & $-0.476^{* *}$ & 0.338 \\
\hline $\begin{array}{l}\text { Total number of } \\
\text { tillers per plant }\end{array}$ & 0.100 & $0.372^{\star \star}$ & $-0.215^{*}$ & 0.114 & & $0.718^{\star \star *}$ & 0.125 & 0.027 & $-0.453^{*}$ & 0.108 & 0.091 & 0.305 & 0.127 \\
\hline $\begin{array}{l}\text { Total number of } \\
\text { panicle per plant }\end{array}$ & 0.143 & $0.345^{\star \star}$ & $-0.229^{*}$ & 0.100 & $0.965^{\star \star}$ & & 0.003 & $-0.364^{\star}$ & -0.319 & 0.229 & 0.185 & 0.242 & 0.300 \\
\hline Panicle length & 0.271 & -0.009 & $0.444^{\star \star *}$ & 0.184 & -0.119 & -0.104 & & $0.613^{\star *}$ & 0.043 & -0.215 & -0.019 & 0.01 & $0.544^{\star *}$ \\
\hline $\begin{array}{l}\text { Total number of } \\
\text { grains per } \\
\text { panicle }\end{array}$ & $0.574^{\star \star}$ & 0.130 & $0.323^{\text {** }}$ & $0.308^{\star \star}$ & -0.023 & 0.053 & $0.462^{\star *}$ & & -0.159 & $-0.579^{\star \star}$ & $-0.406^{\star}$ & 0.109 & 0.250 \\
\hline $\begin{array}{l}\text { Percentage of } \\
\text { filled grain }\end{array}$ & $0.328^{* \star}$ & $0.359^{* \star}$ & -0.037 & 0.174 & 0.197 & 0.213 & -0.141 & 0.236 & & $0.536^{* *}$ & $0.440^{\star}$ & $-0.548^{* \star}$ & $0.447^{\star}$ \\
\hline $\begin{array}{l}\text { One hundred } \\
\text { grain weight }\end{array}$ & $-0.443^{* \star}$ & $-0.449^{* \star}$ & $0.260^{*}$ & -0.139 & -0.129 & -0.152 & 0.032 & $-0.321^{*}$ & $-0.367^{\star \star}$ & & $0.736^{* *}$ & $-0.484^{* *}$ & 0.230 \\
\hline Grain width & 0.052 & -0.170 & $0.276^{*}$ & 0.056 & 0.013 & 0.013 & 0.131 & 0.064 & 0.040 & $0.456^{\star \star}$ & & $-0.807^{\star \star}$ & 0.329 \\
\hline Grain length & $-0.451^{\star \star}$ & $-0.443^{\star \star}$ & 0.079 & $-0.236^{*}$ & -0.174 & -0.184 & 0.151 & $-0.342^{\star \star}$ & $-0.639^{\star \star}$ & $0.702^{\star \star}$ & 0.020 & & -0.320 \\
\hline Yield per plant & $0.441^{\star \star}$ & $0.372^{\star \star}$ & -0.068 & $0.341^{\star \star}$ & $0.624^{* \star}$ & $0.670^{\star *}$ & $0.228^{*}$ & $0.521^{\star *}$ & $0.476^{\star \star}$ & -0.198 & 0.151 & $-0.368^{* *}$ & \\
\hline
\end{tabular}

*.Correlation is significant at $\mathrm{p} \leq 0.05$ probability level; **, Correlation is significant at $\mathrm{p} \leq 0.01$ probability level; Numbers in bold show moderate $(0.3<\mathrm{r}<0.5$ and $-0.5<\mathrm{r}<-0.3)$ and strong $(\mathrm{r} \geq 0.5$ and $\mathrm{r} \leq-0.5)$ correlations. The background color (from light yellow to dark orange) shows the lowest $r$ value to the highest $r$ value.

The number of days-to-flowering was found to have a moderate positive correlation to the number of tillers $(\mathrm{r}=0.372 ; \mathrm{p}<0.01)$ and panicles per plant $(\mathrm{r}=0.345 ; \mathrm{p}<0.01)$ since the number of tillers was positively correlated to the number of panicles $(\mathrm{r}=0.965 ; \mathrm{p}<0.01)$. A similar trend was observed for the days-to-mature and the tiller number $(\mathrm{r}=0.470)$ when 224 rice accessions with different origins were evaluated at a research station of the Africa Rice Centre under the Sahelian environment (Ndour et al., 2016). In addition, a study by Seo et al. (2018) on 87 rice accessions from six countries found that days-to$50 \%$ flowering and days-to- $80 \%$ maturity were positively correlated with tiller number and panicle number. The findings suggested that the correlation of these traits may not be affected by rice varieties, geographical and planting methods.

Environmental factors including temperature extremes, drought and nutrient efficiencies may reduce the number of panicle branches and/or spikelets and reduce pollen viability that form the rice yield components (Smith and Dilday 2003).
The heading date is among the key factors which determine the commercial potential of a rice variety (Guo et al., 2013). Although the rice varieties with prolonged period of vegetative growth may have a higher percentage of filled grains and yield per plant, the trait was found to be negatively correlated to $100-\mathrm{GW}$ ( $\mathrm{r}=-0.449$; $\mathrm{p} \leq 0.01)$. In addition, the $100-\mathrm{GW}$ was also negatively correlated to the total number of grains per panicle $(r=-0.321 ; p \leq 0.01)$ and percentage of filled grains $(\mathrm{r}=-0.367 ; \mathrm{p} \leq 0.01)$. Evaluation of 37 rice genotypes in Nigeria by Abraham et al. (2017) also showed that the days-to-booting and days-tomaturity were negatively correlated with 1000 grain weight $(\mathrm{r}=-0.82 ; \mathrm{p} \leq 0.01$ and $\mathrm{r}=-0.81$; $\mathrm{p} \leq 0.01$, respectively). The same authors also reported negative correlation of 1000-grain weight with the number of filled spikelet $(r=-0.65$; $\mathrm{p} \leq 0.01)$ and total number of spikelet $(\mathrm{r}=-0.78$; $\mathrm{p} \leq 0.01)$. In addition, negative correlation between 1000-grain weight and number of filled grain $(r=-0.443 ; p \leq 0.01)$ was also reported among 
the 30 jhum rice genotypes in Bangladesh (Akter et al., 2018).

A lesser number of grains in the same panicle that compete for the same photosynthetic source for grain filling may enable the rice varieties to achieve a higher 100-GW. The distribution of photosynthetic source to rice grains on the same panicle during grain filling could be a limiting factor to grain filling. Prioritization of the 100GW in some grains, may cause the increase of unfilled grains. The $100-\mathrm{GW}$ was also positively correlated to both grain width $(\mathrm{r}=0.456 ; \mathrm{p} \leq 0.01)$ and grain length $(\mathrm{r}=0.702 ; \mathrm{p} \leq 0.01)$ of lowland indica rice varieties. Our results concurred with the findings of Akter et al. (2018) that reported a positive correlation of 1000 -grain weight with grain breadth/width $(r=0.387 ; \mathrm{p} \leq 0.05)$ and grain length $(\mathrm{r}=0.565 ; \mathrm{p} \leq 0.001)$ among 30 jhum rice genotypes in Bangladesh. Besides, Xie et al. (2013) also revealed that the grain weight was positively correlated with grain width and length among 408 indica rice in China. Akter et al. (2018) also reported a negative correlation between grain length and the number of filled grain $(r=0.390$; $\mathrm{p} \leq 0.05)$. Similar to $100-\mathrm{GW}$, grain length was negatively affected by plant height, late flowering, high number of grains per panicle and high percentage of filled grains. The percentage of filled grains most probably limits the yield of both Bahagia and MR219. The distribution of sources may be prioritized on only a small percentage of grains that were fully filled and these filled grains have above average 100-GW and size. Bahagia with a yield of $52.14 \pm 7.96 \mathrm{~g}$ has high panicle number (22) and moderately high total grain number per panicle (224), average 100-GW and grain size but poor grain filling (37\%). Meanwhile, MR219 (with a yield of 45.99 $\pm 11.19 \mathrm{~g}$ per plant) has an average panicle number (18), moderately high total grain number per panicle (201) and slightly better percentage of filled grains $(43.5 \%)$ than Bahagia.

The plant height, days-to-flowering, flag leaf width, total number of tillers/panicles, total number of grains per panicle and percentage of filled grains contribute to the total rice yield. Nevertheless, the 100-GW and grain length were not the determinants of the total grain yield for the lowland indica rice varieties being analyzed. In summary, lowland rice varieties tend to achieve a higher yield by producing more tillers/panicles and more grains per panicles. Due to that, these varieties may prolong their vegetative phase to accumulate more photosynthates that can be partition to fill up more grains. This was reflected in Mahsuri which has prolonged vegetative growth and a yield of $56.81 \pm 17.13 \mathrm{~g}$ per plant. Mahsuri has an average panicle number (18) but high total grain number per panicle (305) and 77\% of filled grains that compensate for low grain weight and small grains. The small grain weight and size of this variety may be due to a limited photosynthetic source which was distributed to a high number of grains that serve as sinks. Since the rice breeding objective of MARDI focused on traits such as semi dwarf, a maturation period around 100-115 days, heavy grain weight, long and slender rice (www.mada.gov.my), the more recently developed rice varieties such as MR284, MR263 and SIRAJ showed average 100-GW and size but poor percentage of filled grains.

\section{Vegetative traits of upland rice varieties}

The plant height of upland rice ranged from 142$162 \mathrm{~cm}$ (Figure 3a), with Bokilong and Pandasan being the shortest and Gonsulak and Tomou being the tallest rice varieties. The average height of upland rice varieties was found to be higher than that of the lowland rice varieties analyzed in this study, and these upland rice varieties have not been improved through breeding. The average days-to-flowering of the upland rice varieties ranged from 114-135 days (Figure 3b), with Pandasan being the earliest flowering upland rice variety while Kuku Balam was the last upland rice variety to flower. The flag leaf length of upland rice varieties ranged from $32-57 \mathrm{~cm}$ (Figure 3c) while the flag leaf width ranged from $1.90-2.14 \mathrm{~cm}$ (Figure 3d). Generally, the upland rice varieties have longer and wider flag leaves compared to the lowland rice varieties. Pandasan was found to have short and wide flag leaves while Kuku Balam has long and narrow flag leaves. The features may depend on the genetic backgrounds of the rice varieties. The number or tillers ranged from the lowest at $2.20 \pm 0.45$ in Pandasan to the highest at $3.20 \pm 0.45$ in Kuku Balam (Figure 3e). On average, the number of tillers per plant in upland rice varieties was about 7 -fold less than the lowland rice varieties. Since the number of final effective panicles was reported to have strong positive correlation to the number of tillers (Bian 
et al., 2013), and grain yield was found to have a high correlation with the number of productive tillers (Yaqoob et al., 2012), the low number of tillers could be the cause of low yield in these upland rice varieties.

\section{Yield traits of upland rice varieties}

Almost all tillers developed into panicles in upland rice varieties (Figure 4a), hence the number of panicles per plant in upland rice varieties was also about 7 -fold less than the lowland rice varieties. The panicle length of the upland rice varieties ranged from $29.78-36.56 \mathrm{~cm}$, with a mean of $33.09 \pm 2.74 \mathrm{~cm}$, which was longer than that of the lowland rice varieties $(24.22 \pm 1.75 \mathrm{~cm})$. The total number of grains per panicle ranged between 126261 , with a mean of $200.01 \pm 58.11$ which was also higher than that of the lowland rice varieties (176.53 448.97). Gonsulak and Bokilong which have long panicles $(36.58 \pm 2.38 \mathrm{~cm}$ and $260.25 \pm 23.21 \mathrm{~cm}$, respectively) also have the highest number of grains per panicle (Figure $4 \mathrm{~b}$ ) while Pandasan which has the shortest panicle length $(29.78 \pm 1.24 \mathrm{~cm})$, has the least number of grains per panicle. However, the percentage of filled grains in Bokilong was among the lowest $(33.77 \pm 8.50 \%)$, second to that of Kuku Balam $(28.41 \pm 5.60 \%)$. Pandasan which has the least total number of grains per panicle has the highest percentage of filled grains (81.03 $\pm 3.63 \%)$. Gonsulak which has the highest number of grains per panicle also has high percentage of filled grains $(74.19 \pm 9.99 \%)$, hence a higher yield per plant $(13.27 \pm 2.85 \mathrm{~g})$ compared to other upland rice varieties. The $100-\mathrm{GW}$, grain width and grain length of Gonsulak also contributed to a higher yield per plant compared to other upland rice varieties. The mean $100-\mathrm{GW}$ of upland rice varieties $(2.88 \pm 0.39 \mathrm{~g})$ was higher than that of lowland rice varieties $(2.06 \pm 0.27 \mathrm{~g})$. The $100-\mathrm{GW}$ of upland rice varieties ranged from the lowest at $2.20 \mathrm{~g}$ (Bokilong) to the highest at $3.34 \mathrm{~g}$ (Pandasan) (Figure 4d). Kuku Balam which has a lower number of filled grains also has a low 100GW indicating a poor grain filling in this rice variety.

The grain width of the upland rice varieties analyzed ranged from $0.23-0.33 \mathrm{~cm}$ with the lowest in Bokilong and Kuku Balam and the highest in Taragang, Tomou and Pandasan (Figure 4f). On average, the upland rice varieties have a slightly wider grain width $(0.29 \pm 0.04 \mathrm{~cm})$ than the lowland rice varieties $(0.23 \pm 0.02 \mathrm{~cm})$ but comparable grain length $(0.90 \pm 0.05 \mathrm{~cm}$ and $0.88 \pm 0.07 \mathrm{~cm}$ for lowland and upland rice varieties, respectively). The grain length of upland rice varieties ranged from $0.93-1 \mathrm{~cm}$ for Kuku Balam and Bokilong and 0.87-0.89 cm for Taragang, Pandasan, Tomou and Gonsulak (Figure 4g). Kuku Balam and Bokilong have long and narrow grains as in the indica varieties while the others have shorter and wider grains, resembling the shape of japonica rice grains.

The mean yield per plant of the upland rice varieties was $9.15 \pm 2.90 \mathrm{~g}$ which was about 4 -fold lower than that in the lowland rice varieties (37.73 $\pm 14.16 \mathrm{~g} /$ plant). Among the upland rice varieties, Gonsulak and Tomou have the highest yield per plant $(13.27 \pm 2.85 \mathrm{~g} /$ plant and $11.66 \pm 1.46 \mathrm{~g} /$ plant, respectively) while Bokilong has the lowest yield $(6.84 \pm 1.44 \mathrm{~g} /$ plant $)$, mainly due to poor grain filling (low percentage of filled grains and also low 100-GW). The high total grain number per panicle could not compensate for its poor grain filling. Both Kuku Balam and Taragang that have low yield per plant $(7.75 \pm 0.24 \mathrm{~g} /$ plant and $(8.11 \pm 1.43 \mathrm{~g} /$ plant, respectively), have low number of tillers, total grain number per panicle and poor percentage of filled grains. In addition, Kuku Balam has low 100-GW that contributes to poor yield per plant. Although Pandasan has good percentage of filled grains and 100-GW, the overall yield $(7.28 \pm 1.66 \mathrm{~g} /$ plant $)$ was poor due to a low number of tillers and total grain number per panicle.

\section{Factors affecting yield of upland rice varieties}

Pearson correlation coefficients (Table 1) showed that the yield per plant of the upland rice varieties could be determined by the plant height, panicle length and percentage of filled grains that have positive correlation to yield. Among these three traits, the plant height and panicle length were highly correlated to each other $(r=0.670 ; p \leq 0.01)$. Upland rice varieties that flowered later seemed to have longer but narrower flag leaves, lower percentage of filled grains and lower 100-GW. Late flowering and a prolonged vegetative growth could be a disadvantage to the upland rice varieties by reducing the percentage of filled grains and 100-GW. The length of flag leaf positively affected the number of tillers and 
panicles, and panicle length while the total number of grains per panicle depends on the panicle length $(r=0.613 ; p \leq 0.01)$. The length and width of flag leaves have negative $(r=-0.671$; $\mathrm{p} \leq 0.01)$ and positive $(\mathrm{r}=0.563 ; \mathrm{p} \leq 0.01)$ correlations to the percentage of filled grains, respectively; while the total number of tillers per plant was likely to reduce the percentage of filled grain $(r=-0.453 ; \mathrm{p} \leq 0.05)$. a



C

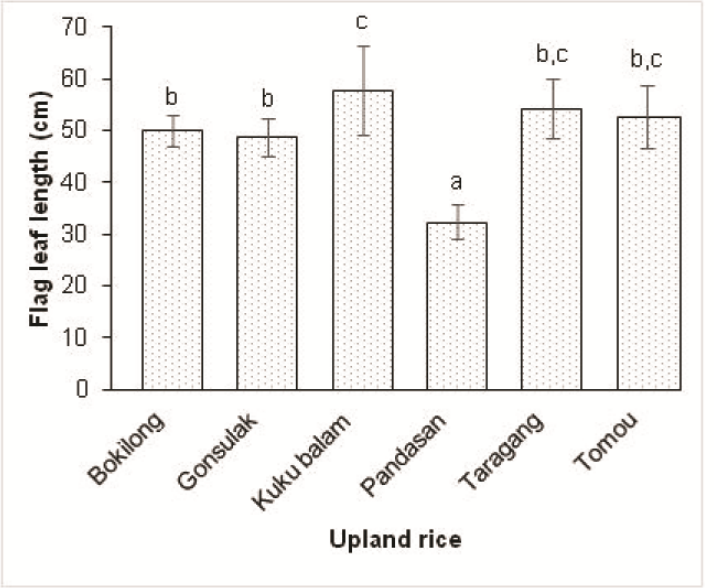

e

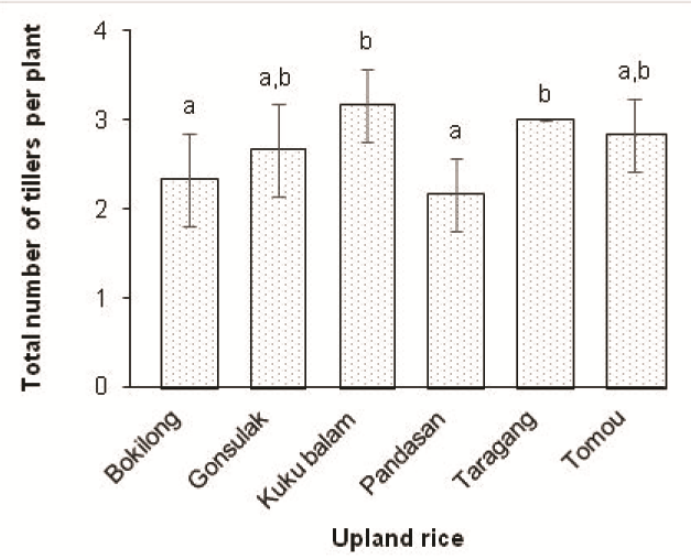

b

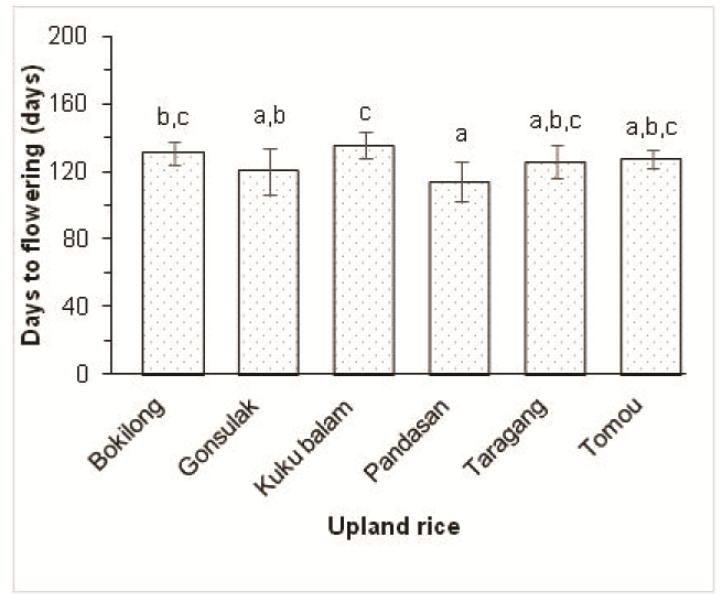

d

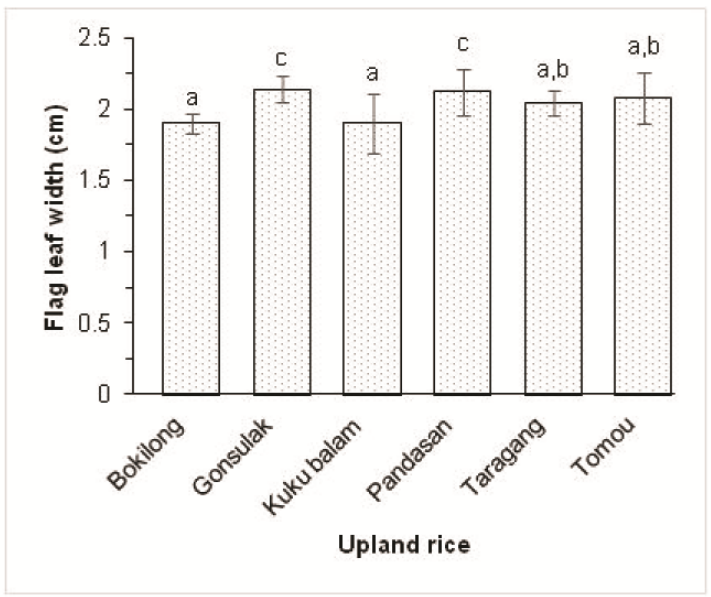

Figure 3. Comparison of vegetative traits from 6 upland rice varieties. a, Plant height; b, Days to flowering; c, Flag leaf length; d, Flag leaf width; e, Total number of tiller per plant. Statistically significant difference between the means $(p<0.05)$ is indicated by different letters. 
a



C

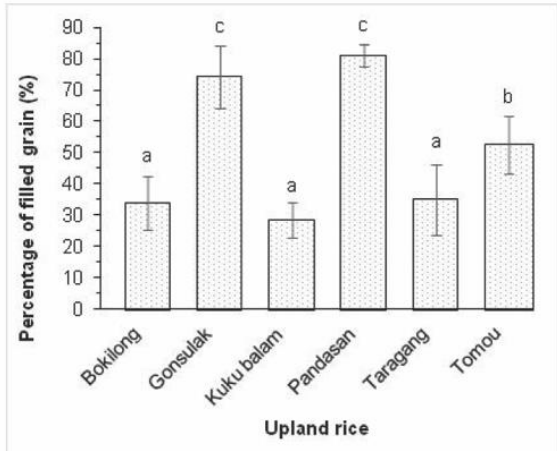

e

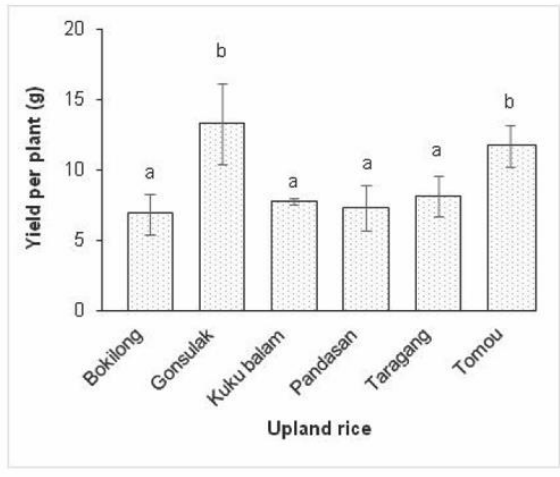

f
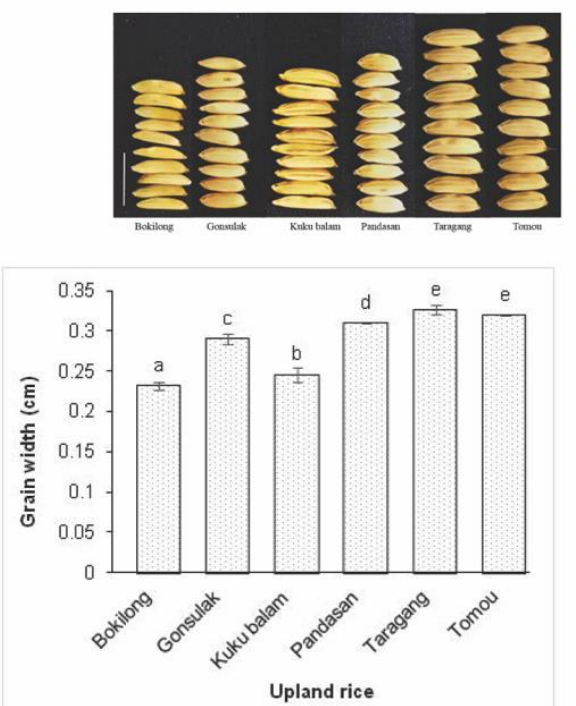

b

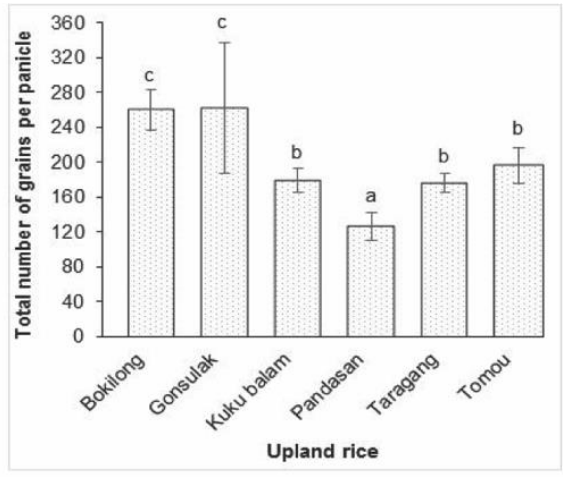

d

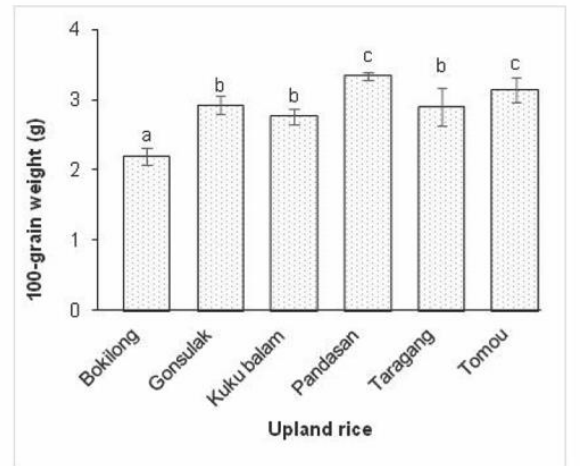

g
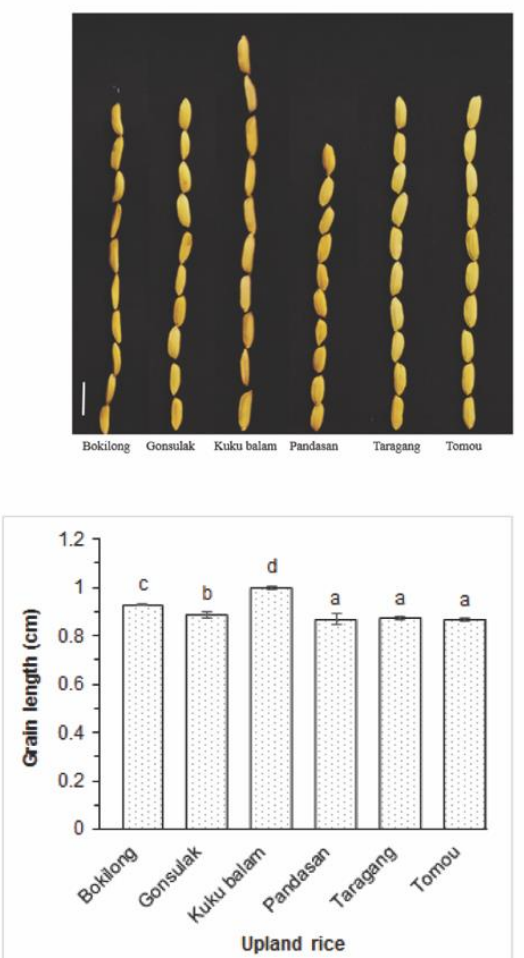

Figure 4. Comparison of yield traits from 6 upland rice varieties. a, Total number of panicle; b, Total number of grains; c, Percentage of filled grains; d, 100-grain weight; e, Yield per plant; f, Grain width; g, Grain length. Scale bar $=1 \mathrm{~cm}$. Statistically significant difference between the means $(p<0.05)$ is indicated by different letters. 
The 100-GW of upland rice varieties could be negatively affected by the total number of grains per panicle $(\mathrm{r}=-0.579 ; \mathrm{p} \leq 0.01)$ but positively correlated to the percentage of filled grains $(\mathrm{r}=0.536 ; \mathrm{p} \leq 0.01)$. However, the number of grains per panicle of upland rice varieties may not affect the percentage of filled grains directly, possibly because these varieties normally have a low number of tillers hence a low number of grains per plant. The partition of photosynthate to the sinks may not be limited since the total number of grains per plant in these upland rice varieties was low. Panicle length and percentage of filled grains contributed positively to the yield per plant of upland rice varieties possibly through the number of grains per panicle and the 100-GW indirectly.

The grain width of upland rice varieties was positively correlated to the width of flag leaves $(\mathrm{r}=0.494 ; \mathrm{p} \leq 0.01)$, percentage of filled grains $(\mathrm{r}=0.440 ; \quad \mathrm{p} \leq 0.05)$ and $100-\mathrm{GW} \quad(\mathrm{r}=0.736$; $\mathrm{p} \leq 0.01)$ but negatively correlated to the number of grains per panicle $(r=-0.406 ; p \leq 0.05)$ and grain length $(r=-0.807 ; p \leq 0.01)$. On the other hand, the grain length of these upland rice varieties was negatively correlated to width of flag leaves ( $\mathrm{r}=$ $0.476 ; \mathrm{p} \leq 0.01$ ), percentage of filled grains ( $\mathrm{r}=$ $0.548 ; \mathrm{p} \leq 0.01)$ and $100-\mathrm{GW}(\mathrm{r}=-0.484 ; \mathrm{p} \leq 0.01)$ but positively correlated to the length of flag leaves ( $r=0.406 ; \mathrm{p} \leq 0.05)$. Kadidaa et al. (2017) also reported a high positive correlation between panicle length, filled grain number, number of grains per panicle and grain weight with grain yield/plant among 22 local upland rice cultivars of North Buton, Indonesia; while Demewez et al. (2014) reported a positive correlation between grain yield with panicle length, number of spikelet per panicle, number of fertile tillers per plant and number of filled grains per panicle among 12 upland rice genotypes. Unfortunately, we did not find any report on the correlation between grain width and length with other traits among the upland rice varieties.

\section{Comparison of agronomic traits of lowland and upland rice varieties}

Although plant height was positively correlated to yield per plant in both lowland and upland rice varieties, vegetative growth may have different significance on other yield traits of lowland and upland rice varieties, respectively (Table 1). For example, the plant height was only positively correlated to the panicle length of upland rice varieties but not the lowland rice varieties. The width of flag leaf was correlated to the percentage of filled grains, grain width and grain length of upland rice varieties only; while the length of flag leaves was positively correlated to the panicle length in both upland and lowland rice varieties. The length of the vegetative phase negatively affected the 100-GW in both upland and lowland rice varieties. Previously, a positive correlation of plant height and panicle length was also reported by Sohrabi et al. (2012) and Lasalita-Zapico et al. (2010) in upland rice, while Demewez et al. (2014) reported a negative correlation between 1000grain weight to the days-to- $50 \%$ heading and days-to-maturity, respectively. On the other hand, a positive correlation of plant height and yield among lowland rice was reported by Zhao et al. (2020) whereas a negative correlation of days-tobooting and maturity with 1000 -grain weight was recorded by Abraham et al. (2017). A shorter vegetative growth may help to produce heavier grains, however this trait only contributes positively to the yield per plant of lowland rice varieties but not the yield of the upland rice varieties. This may due to the facts that the yield per plant was correlated to a few other yield traits including the total number of tillers or panicle per plant, percentage of filled grains and grain length (Table 1).

The total number of tillers or panicles in upland rice varieties was remarkably lower (up to 7 -fold lower) than that in lowland varieties. A lower ratio of auxin and cytokinin could limit auxiliary bud development and branching hence limiting the development of tillers in rice (Müller and Leyser, 2011). The number of tillers/panicles per plant contributed positively to the yield per plant of lowland rice varieties whereas it affected the percentage of filled grains in upland rice varieties. A positive correlation of tiller number and grain yield in lowland rice was also reported by Seo et al. (2019) whereas a positive correlation between tiller or panicle number with the number of tillers and between productive tillers with the number of filled grains among 22 local upland rice cultivars of North Buton, Indonesia was recorded by Kadidaa et al. (2017). The number of grains per panicle was possibly determined by the panicle length in both upland and lowland rice varieties, 
and the numbers of grains per panicle in these rice varieties may not be significantly different.

The total number of grains per panicle correlated negatively to $100-\mathrm{GW}$ but not to the percentage of filled grains in both upland and lowland rice varieties. Meanwhile, the percentage of filled grains correlated positively $(\mathrm{r}=0.536$; $\mathrm{p} \leq 0.01)$ to $100-\mathrm{GW}$ of upland rice varieties but correlated negatively $(\mathrm{r}=-0.367 ; \mathrm{p} \leq 0.01)$ to 100 GW of lowland rice varieties. A positive correlation was also established between the number of filled grains with 1000-grain weight in 22 local upland rice cultivars of North Buton, Indonesia by Kadidaa et al. (2017), while Akter et al. (2018) reported a negative correlation between the number of filled grain and 1000-grain weight among 30 jhum rice genotypes in Bangladesh. In addition, Ilieva et al. (2019) also reported a negative correlation between the number of grains per panicle with 1000-grain weight among 14 Italian rice cultivars. Although the numbers of grains per panicle in these rice varieties were not significantly different, a fewer number of tillers or panicles in upland rice varieties may produce a significantly lower total number of grains per plant than in lowland rice varieties. Assuming that the photosynthetic source of these upland and lowland rice varieties were not significantly different, the upland rice varieties may have sufficient photosynthates to support grain filling for most (if not all) grains and produce a higher 100-GW, whereas the lowland rice varieties that produce more tillers hence more grains per plant may not have sufficient photosynthates to cater for all grains. Some of these grains may be partially filled thus a lower 100-GW in in lowland rice varieties. In summary, the percentage of filled grain was negatively correlated to $100-\mathrm{GW}$ when there was insufficient photosynthates for high number of grains per plant as in lowland rice varieties. In lowland rice varieties, the 100-GW was positive correlated to both grain width and length while the 100-GW in upland rice was positively correlated to grain width but negatively correlated to grain length. The grain length of upland rice varieties was also negatively correlated to the percentage of filled grains and grain width. The common factors that contributed to yield per plant in both upland and lowland rice varieties were plant height and percentage of filled grains. Panicle length was positively correlated to grain yield in upland rice varieties while many other agronomic traits could affect the yield per plant in lowland rice varieties such as total number of tillers, total number of panicles per plant, flag leaf width and days-to-flowering. These findings were supported by previous reports that documented a positive correlation between grain yield and panicle length in upland rice varieties (Kadidaa et al., 2017; Demewez et al., 2014); and also between grain yield and tiller number, panicle number, days-to- $50 \%$ flowering and days-to- $80 \%$ maturity, respectively (Seo et al., 2018). The upland rice varieties have a slightly higher average total grain number per panicle in compensation of a low number of panicles, nevertheless the overall yield per plant in these rice varieties was still far behind the yield per plant in lowland rice varieties (30$60 \%$ lower). The compensation in total grain numbers per panicle was not sufficiently significant to affect the total yield per plant most probably due to a low total number of grains per plant. Despite a high 100-GW in general, some of these upland rice varieties have less than $50 \%$ percentage of filled grains.

\section{CONCLUSION}

In this study, we have recorded the agronomical traits of a total of 17 lowland rice varieties and 6 upland rice varieties under the greenhouse condition to minimize the environmental factors that may contribute to differences in these traits under natural stresses in open field. Due to the differences in the water requirement of upland and lowland rice varieties, they were planted in different soil types that withhold different water capacity. Other than that, the differences among the rice varieties were mainly contributed by the genetics of the plants. In addition, the understanding of the contribution of the agronomical traits to the total yield per plant would provide further information for the selection of genetic resources for future rice improvement. Identifying rice germplasms for different agronomical characters would help in breeding programs. 


\section{ACKNOWLEDGEMENTS}

We acknowledge Gene Bank and Seed Centre, Malaysian Agricultural Research and Development Institute (MARDI), Kepala Batas, Malaysia for providing the rice seeds. The project was supported by Ministry of Education, Malaysia under the Fundamental Research Grant Scheme (Project No. FRGS/1/2016/STG05/UPM/ 02/18). Teh CY was supported by the UPM postdoctoral scheme. Mohd Kasim NA was supported by FRGS/1/2016/STG05/UPM/ 02/18 and Graduate Research Fund (GRF) from UPM.

\section{REFERENCES}

Abraham, O. G., Nwokeocha, C. C., Akinwale, R. O., \& Faluyi, J. O. 2017. Screening for yield related characters in some landrace accessions of Oryza sativa Linn. in Nigeria. Journal of Plant Sciences 12: 52-58.

Akter, N., Khalequzzaman, M., Islam, M. Z., Mamun, M. A. A., \& Chowdhury, M. A. Z. 2018. Genetic variability and character association of quantitative traits in jhum rice genotypes. SAARC Journal of Agriculture 16: 193-203.

Asante, M. D., Adjah, K. L., \& Annan-Afful, E. 2019. Assessment of genetic diversity for grain yield and yield component traits in some genotypes of rice (Oryza sativa L.). Journal of Crop Science and Biotechnology 22: 123-130.

Berahim, Z., Panhwar, Q. A., Ismail, M. R., Saud, H. M., Mondal, M. M. A., Naher, U. A., \& Islam, M. R. 2014. Rice yield improvement by foliar application of phytohormones. Journal of Food, Agriculture and Environment 12: 399-404.

Bian, J., He, H., Shi, H., Zhu, C., Peng, X., Li, C., Fu, J., He, X., Hu, L., Chen, X., \& Ouyang, L. 2013. Dynamic QTL detection and analysis of tiller number before and after heading in japonica rice. Australian Journal of Crop Science 7: 1189-1197.

Counce, P. A., Siebenmorgen, T. J., Poag, M. A., Holloway, G. E., Kocher, M. F., \& Lu, R. 1996. Panicle emergence of tiller types and grain yield of tiller order for direct-seeded rice cultivars. Field Crops Research 47: 235-242.

Demewez, F., Alemayehu, G., Siddalingaiah, M., \& Tadesse, T. 2014. Genetic variability, heritability and correlation coefficient analysis for yield and yield component traits in upland rice (Oryza sativa L.). East African Journal of Sciences 8: 147-154.

Dong, Y., Pei, X., Yuan, Q., Wu, H., Wang, X., Jia, S., \& Peng, Y. 2010. Ecological, morphological and genetic diversity in Oryza rufipogon Griff (Poaceae) from Hainan Island, China. Genetic Resources and Crop Evolution 57: 915-926.

Efendi, Kesumawaty, E., Zakaria, S., Bakhtiar, \& Syafruddin. 2015. Morpho-agronomic performances of rice (Oryza sativa L.) landraces under organic cultivation of SRI method. International Journal of Agricultural Research 10: 74-82.

Fukuoka, S., Suu, T. D., Ebanna, K., \& Trinh, L. N. 2006. Diversity in phenotypic profiles in landraces populations of Vietnamese rice: a case study of agronomic characters for conserving crop genetic diversity on farm. Genetic Resources and Crop Evolution 53: 753-761.

Guo, L., Zhang, Z, H., \& Zhuang, J. Y. 2013. Quantitative trait loci for heading date and their relationship with genetic control of yield traits in rice (Oryza sativa). Rice Science 20:1-12.

Guvvala, L. D., Koradi, P., Shenoy, V., \& Marella, L. S. 2013. Making an Indian traditional rice variety Mahsuri, bacterial blight resistant using marker-assisted selection. Journal of Crop Science and Biotechnology 16: 111.

Ilieva, V., Ruzdik, N. M., Mihajlov, L., \& Ilievski, M. 2019. Assessment of agro-morphological variability in rice using multivariate analysis. Journal of Agriculture and Plant Sciences 17: 79-85.

Jennings, P. R., Coffman, W. R., \& Kauffman, H. E. 1989. Rice improvement. Manila: International Rice Research Institute.

Kadidaa, B., Sadimantara, G. R., \& Suaib, S. L. Muhidin. 2017. Genetic diversity of local upland rice (Oryza sativa L.) genotypes based on agronomic traits and yield potential in North Buton Indonesia. Asian Journal of Crop Science 9: 109117.

Lasalita-Zapico, F. C., Namocatcat, J. A., \& Cariño-Turner, J. L. 2010. Genetic diversity analysis of traditional upland rice cultivars in Kihan, Maapatan, Sarangani Province, Philippines using morphometric markers. Philippine Journal of Science 139: 177-180.

Li, R., Jiang, T. B., Xu, C. G., Li, X. H., \& Wang, X. K. 2000. Relationship between morphological and genetic differentiation in rice (Oryza sativa L.). Euphytica 114: 1-8.

Müller, D. \& Leyser, O. 2011. Auxin, cytokinin and the control of shoot branching. Annals of Botany 107: 1203-1212.

Narenoot, K., Monkham, T., Chankaew, S., Songsri, P., Pattanagul, W., \& Sanitchon, J. 2017. Evaluation of the tolerance of Thai indigenous upland rice germplasm to early drought stress using multiple selection criteria. Plant Genetics Resources- Characterization and Utilization 15: 109-118.

Nascimento, W. F., da Silva, E. F., \& Veasey, E. A. 2011. Agromorphological characterization of upland rice accessions. Scientia Agricola (Piracicaba, Brazil) 68: 652-660.

Ndour, D., Diouf, D., Bimpong, I. K., Sow, A., Kanfany, G., \& Manneh, B. 2016.

Agro-morphological evaluation of rice (Oryza sativa L.) for seasonal adaptation in the Sahelian environment. Agronomy 6: 1-19.

Nwilene, F. E., Oikeh, S. O., Agunbiade, T. A., Oladimeji, O., Ajayi, O., Sié, M., Gregorio, G. B., Togol, A., \& Touré, A. D. 2008. Growing lowland rice: A production handbook. Africa Rice Center (WARDA).

Oikeh, S. O., Nwilene, F. E., Agunbiade, T. A., Oladimeji, O., Ajayi, O., Mande, S., \& Samejima, H. 2008. Growing upland rice: a production handbook. Cotonou, Benin: Africa Rice Center (WARDA).

Pachauri, A. K., Sarawgi, A. K., Bhandarkar, S., \& Ojha, G. C. 2017. Agro-morphological characterization and morphological based genetic diversity analysis of rice (Oryza sativa L.) germplasm. Journal of Pharmacognosy and Phytochemistry 6: 75-80.

Parikh, M., Motiramani, N. K., Rastogi, N. K., \& Sharma, B. 2012. Agro-morphological characterization and assessment of variability in aromatic rice germplasm. Bangladesh Journal of Agricultural Research 37: 1-8.

Patra, B. C., \& Dhua, S. R. 2003. Agro-morphological diversity scenario in upland rice germplasm of Jeypore tract. Genetic Resources and Crop Evolution 50: 825-828.

Soe, I., Tamu, A., Asante, M.D., Nyadanu, D., \& Akromah, R. 2019. Genetic diversity analyses of rice germplasm using morphological traits. Journal of Plant Breeding and Crop Science 11: 128-136.

Smith, C. W. \& Dilday, R. H. 2003. Rice: Origin, history, technology and production. Hoboken: John Wiley and Sons 
Sohrabi, M., Rafii, M. Y., Hanafi, M. M., Siti Nor Akmar , A., \& Latif, M. A. 2012. Genetic diversity of upland rice germplasm in Malaysia based on quantitative traits. The Science World Journal 2012: 1-9.

Teh, C.-Y., Mohd Kasim, N. A., Yusop, M. R., Namasivayam, P., Musa, M. H., \& Ho, C.-L. 2019. Association analysis of rice grain traits with single nucleotide polymorphisms in a Brassinosteroid-insensitive 1 (BRI1)-associated receptor kinase 1-like gene. Plant Gene 19: 100188.

Xie, L., Tang, S., Chen, N., Luo, J., Jiao, G., Shao, G., Wei, X., \& $\mathrm{Hu}$, P. 2013. Rice grain morphological characteristics correlate with grain weight and milling quality. Cereal Chemistry 90: 587-593.

Yaqoob, M., Anjum, R., Hussain, M., \& Shah, M. J. 2012. Genetic diversity analysis and character association in some Chinese hybrid rice under dry conditions. Pakistan Journal of Agricultural Research 25: 249-256.

Zainuddin, H., Mokhtar, A., Amzah, B., Hashim, M., \& Abd Ghafar, M. B. 2012. Enam varieti padi popular MARDI. Buletin Teknologi MARDI 1: 1-10.

Zeng, Y., Shen, S., Li, Z., Yang, Z., Wang, X., Zhang, H., \& Wen, G. 2003. Ecogeographic and genetic diversity based on morphological characters of indigenous rice (Oryza sativa L.) in Yunnan, China. Genetic Resources and Crop Evolution 50: 567-577.

Zhang, B., Ye, W., Ren, D., Tian, P., Peng, Y., Gao, Y., \& Qian, Q. 2015. Genetic analysis of flag leaf size and candidate genes determination of a major QTL for flag leaf width in rice. Rice 8: 2.

Zhang, Y., Yu, C., Lin, J., Liu, J., Liu, B., Wang, J., Huang, A., Li, H., \& Zhao, T. 2017. OsMPH1 regulates plant height and improves grain yield in rice. PLoS ONE 12: e0180825.

Zhao, H., Mo, Z., Lin, Q., Pan, S., Duan, M., Tian, H., Wang, S., \&Tang, X. 2020. Relationships between grain yield and agronomic traits of rice in southern China. Chilean Journal of Agricultural Research 80: 72-79. 